\title{
Increasing of Cocoa Farmers Household Income with Two Stage Least Squares Method
}

\author{
Effendy ${ }^{1}$ \\ ${ }^{1}$ Department of Agriculture Economics, Tadulako University, Indonesia \\ Corresponding author: Effendy, Department of Agriculture Economics, Faculty of Agriculture, Tadulako \\ University, Indonesia. E-mail: effendy_surentu@yahoo.com
}

Received: December 4, 2014

Accepted: February 27, 2015 Online Published: April 26, 2015

doi:10.5539/mas.v9n6p120

URL: http://dx.doi.org/10.5539/mas.v9n6p120

\begin{abstract}
This research aimed to analyze the relationship of production decisions, allocation of labor and consumption decisions the cocoa farming with side-grafting technology in order to increase household income of farmers. The method used was survey where the number of samples were 98 household heads, and the sample was determined by simple random sampling. The results showed that the combination simulation by increasing the usage of fertilizer, following agricultural extension and sanitation by $25 \%$ as production decisions had positive impacts in increasing household income of cocoa farmers (18.09\%), labor absorption (7.77\%) and expenses for consumption (15.47\%).
\end{abstract}

Keywords: fertilizer, agricultural extension, sanitation, household, income, cocoa farming

\section{Introduction}

Plantation sub-sector is one of the sub-sectors that supporting economic development in Indonesia. Cocoa is one of the plantation commodities that has an important role in supporting the economic development. Cocoa is an export commodity and has contributed to poverty reduction in Indonesia, especially in rural areas (Neilson, 2008).

Indonesia is one of the producers of cocoa beans to the needs of the world. One of the cocoa producing areas in Indonesia is Sigi Regency. Sigi Regency has implemented side-grafting technology on cocoa trees, but the productivity of cocoa in 1 year was still around 0.67 tonnes.ha $^{-1}$. According to Departemen Pertanian Direktorat Jenderal Perkebunan (2009), cocoa production of side-grafting technology results could reach 1.8 to 2.75 tonnes.ha ${ }^{-1}$. It was because not all of farmers applied the side-grafting technology on unproductive cocoa trees. One of the reasons was the government just looked at the aspect of production alone, without paid attention to the farmers household consumption.

The role of the economic behavior of household in relation to productivity, incomes, and consumption had been widely researched for example in Elly et al. (2009), Siswati and Ariyanto (2012), Rochaeni and Lokolo (2005), Lokolo (2001), and other researchers. The difference with this research lied in the variable extension and sanitation as an exogenous variable in relation to the increasing in household income of cocoa farmers.

There are three main elements that determine the productivity of cocoa trees side-grafting, namely: (1) the usage of seeds / scion, (2) a given nutrient, and (3) maintenance / management of cocoa plants (Neilson, 2008). Maintenance / management of cocoa farming entirely dependent role of farmers household. This management includes the decision-making in terms of: the number of production factors are given, control of pests and plant diseases, ways of handling the production, marketing, and labor arrangements. Labor is allocated to family members working on the farm and non-farm. Labor on cocoa farms is allocated to provide and maintain plant production factors.

Cocoa farmers household ability in increasing cocoa production as a source of income is determined by internal and external household factors. Internal factors are: land, seed, fertilizer, pesticide, the amount and quality of labor, capital, technology mastery, age, experience, and formal education. While external factors are government policies such as the provision of infrastructure, procurement of seeds, extension, field worker assistance, and regulation of the output and input of cocoa production.

Due to the internal and external factors which cause inadequate most farmers sell their products to retailers who 
visit the farmers so that the price which receives by farmers will vary with the price of the large trader. Price that receives by farmers is cheaper when compare if a farmer sells itself. The implication is the influence household decisions in production, labor allocation and consumption decisions.

Phenomena mentioned above is farmers household behaviour as producers in economic activity. Household as producers in an effort to increase the productivity of cocoa with the purpose of increasing income. The increasing income is related with the increasing in household consumption. The higher the household income earned there is a tendency for an increasing in consumption expenses. However, the increasing of income is also highly related to input and output prices. Input and output prices that receive by household are determined by the merchant, on the other hand input prices continue to rise due to the economic conditions of the country of Indonesia to the impacting areas. One way that can be taken is the government policy in terms of input and output pricing.

Factors that affect decision making in the household labor arrangements, production, and consumption are needed to be known. It can be used as the basis of the formulation of policies in increasing household income of farmers. Labor arrangements decision, production decisions and consumption decisions affect each other. So we need to examine the simultaneous analysis of production decisions linkages, labor allocation and consumption decisions in cocoa farming with side-grafting technology in order to increase household income of cocoa farmers. One of the methods that can be used for simultaneous analysis is the Two Stage Least Squares (TSLS). This method has a accuracy level that high enough and data processing that efficient in using time (Koutsoyiannis, 1978).

\section{Method}

The place of research were Sejahtera and Bulili Village, Palolo Sub-district and Nokilalaki Sub-district in Sigi Regency Indonesia. The choice of location research was done purposive, with consideration of both villages including cocoa production areas in Sigi regency Indonesia. The research was conducted for 3 (three) months.

The research population totaled 218 household heads $(\mathrm{HH})$, in Sejahtera Village totaled $106 \mathrm{HH}$ and Bulili Village totaled $112 \mathrm{HH}$. The samples that used in Sejahtera Village totaled $48 \mathrm{HH}$ and Bulili Village totaled 50 HH. Determination of the sample was calculated by the formula in Parel et al. (1973):

$$
\begin{gathered}
n=\frac{N \sum N_{h} s_{h}^{2}}{N^{2} \frac{d^{2}}{z^{2}}+\sum N_{h} s_{h}^{2}} \\
n_{h}=\frac{N_{h}}{N} n
\end{gathered}
$$

where:

$\mathrm{n}=$ number of sample

$\mathrm{N}=$ number of population

$\mathrm{Nh}=$ number of population each village

$\mathrm{d}=$ precision was set at $10 \%$

$\mathrm{z}=1.645(90 \%)$

$\mathrm{sh}=$ variance of each village

$\mathrm{nh}=$ number of sample from each village

Simultaneous equation model was used to answer the research objectives. Simultaneous equations that used in this research consisted of 27 equations, which 13 were the equation of identity, and 14 were the equation of structural. More models as follows: 


\section{The equation of identity}

$\begin{array}{ll}\text { TRRT } & =\text { Lk }+ \text { NonUST } \\ \text { Lk } & =\text { Yk*Pk }- \text { TVC } \\ \text { NonUST } & =\text { CTKDN*UTK } \\ \text { Yk } & =\text { PDTVSk } * \text { LAPk } \\ \text { YkPTSL } & =\text { YkF*EFSTEK } \\ \text { PDTVSPk } & =\text { YkPTSL } / \text { LAPk } \\ \text { LkPTSL } & =\text { YkPTSL*Pk }- \text { TVC } \\ \text { TRRTPTSL } & =\text { LkPTSL }+ \text { NonUST } \\ \text { PPKR } & =(\text { TRRT/JART } / 12 \\ \text { PPKP } & =(\text { TRRTPTSL/JART }) / 12 \\ \text { TCV } & =\text { TK*UTK }+ \text { PU*HPU }+ \text { PEST*HPEST } \\ \text { MDLk } & =\text { TVC } \\ \text { TK } & =\text { TKD }+ \text { TKL }\end{array}$

The equation of structural :

$$
\begin{aligned}
& \text { LAPk }=a_{0}+a_{1} \text { PU }+a_{2} \text { PEST }+a_{3} \text { TK }+a_{4} \text { SANI }+a_{5} \text { UTAN }+\mathrm{U}_{1} \\
& \text { PDTVSk }=b_{0}+b_{1} \text { PTSS }+b_{2} \text { EFSTEK }+b_{3} \text { UTAN }+b_{4} \text { PU }+ \\
& \mathrm{b}_{5} \mathrm{PEST}+\mathrm{b}_{6} \mathrm{TK}+\mathrm{U}_{2} \\
& \text { EFSTEK }=\mathrm{c}_{0}+\mathrm{c}_{1} \mathrm{UR}+\mathrm{c}_{2} \mathrm{PdR}+\mathrm{c}_{3} \text { PENGUT }+\mathrm{c}_{4} \text { FPYL }+\mathrm{c}_{5} \mathrm{FPKS} \\
& +\mathrm{c}_{6} \mathrm{SANI}+\mathrm{U}_{3} \\
& \mathrm{Pk}=\mathrm{d}_{0}+\mathrm{d}_{1} \mathrm{PMSk}+\mathrm{d}_{2} \mathrm{Yk}+\mathrm{d}_{3} \mathrm{KTSk}+\mathrm{U}_{4} \\
& \text { PMSk } \quad=\mathrm{e}_{0}+\mathrm{e}_{1} \mathrm{PdR}+\mathrm{e}_{2} \mathrm{Yk}+\mathrm{e}_{3} \mathrm{SK}+\mathrm{e}_{4} \mathrm{KIPSRk}+\mathrm{U}_{5} \\
& \text { KTSk }=\mathrm{f}_{0}+\mathrm{f}_{1} \mathrm{MDLk}+\mathrm{f}_{2} \mathrm{TKD}+\mathrm{U}_{6} \\
& \text { MDLk }=\mathrm{g}_{0}+\mathrm{g}_{1} \mathrm{KS}+\mathrm{g}_{2} \mathrm{JKUT}+\mathrm{U}_{7} \\
& \text { JKUT }=\mathrm{h}_{0}+\mathrm{h}_{1} \mathrm{Yk}+\mathrm{h}_{2} \mathrm{TRRT}+\mathrm{U}_{8} \\
& \text { PTSS }=\mathrm{i}_{0}+\mathrm{i}_{1} \text { ETNIK }+\mathrm{i}_{2} \mathrm{UR}+\mathrm{i}_{3} \text { PdR }+\mathrm{i}_{4} \text { PENGUT }+\mathrm{i}_{5} \text { JART }+ \\
& \mathrm{i}_{6} \mathrm{FPYL}+\mathrm{U}_{9} \\
& \text { TKL }=\mathrm{j}_{0}+\mathrm{j}_{1} \mathrm{LAPk}+\mathrm{j}_{2} \mathrm{TKD}+\mathrm{U}_{10} \\
& \text { TKD }=\mathrm{k}_{0}+\mathrm{k}_{1} \mathrm{JARTp}+\mathrm{k}_{2} \mathrm{CTKDN}+\mathrm{k}_{3} \mathrm{LAPk}+\mathrm{U}_{11} \\
& \mathrm{CTKDN}=1_{0}+1_{1} \mathrm{TKD}+1_{2} \mathrm{PdR}+1_{3} \mathrm{Lk}+\mathrm{U}_{12} \\
& \text { KS }=\mathrm{m}_{0}+\mathrm{m}_{1} \mathrm{JART}+\mathrm{m}_{2} \text { TRRT }+\mathrm{U}_{13} \\
& \text { PU }=\mathrm{n}_{0}+\mathrm{n}_{1} \mathrm{HPU}+\mathrm{n}_{2} \mathrm{JKUT}+\mathrm{n}_{3} \mathrm{LAPk}+\mathrm{U}_{14}
\end{aligned}
$$

$\begin{array}{ll}\text { TRRT } & =\text { respondents of household income (IDR) } \\ \text { NonUST } & =\text { income outside farming (IDR) } \\ \mathrm{Lk} & =\text { real income of cocoa farming (IDR) } \\ \mathrm{Yk} & =\text { real cocoa production }\left(\mathrm{kg} \cdot \mathrm{year}^{-1}\right) \\ \mathrm{Pk} & \left.=\text { price of cocoa farmers level (IDR. } \mathrm{kg}^{-1}\right) \\ \mathrm{TCV} & =\text { variable cost of cocoa (IDR) } \\ \mathrm{LAPk} & =\text { cocoa crop area (ha) } \\ \mathrm{PU} & =\text { fertilizer }(\mathrm{kg}) \\ \text { PEST } & =\text { pesticide (liter) }\end{array}$




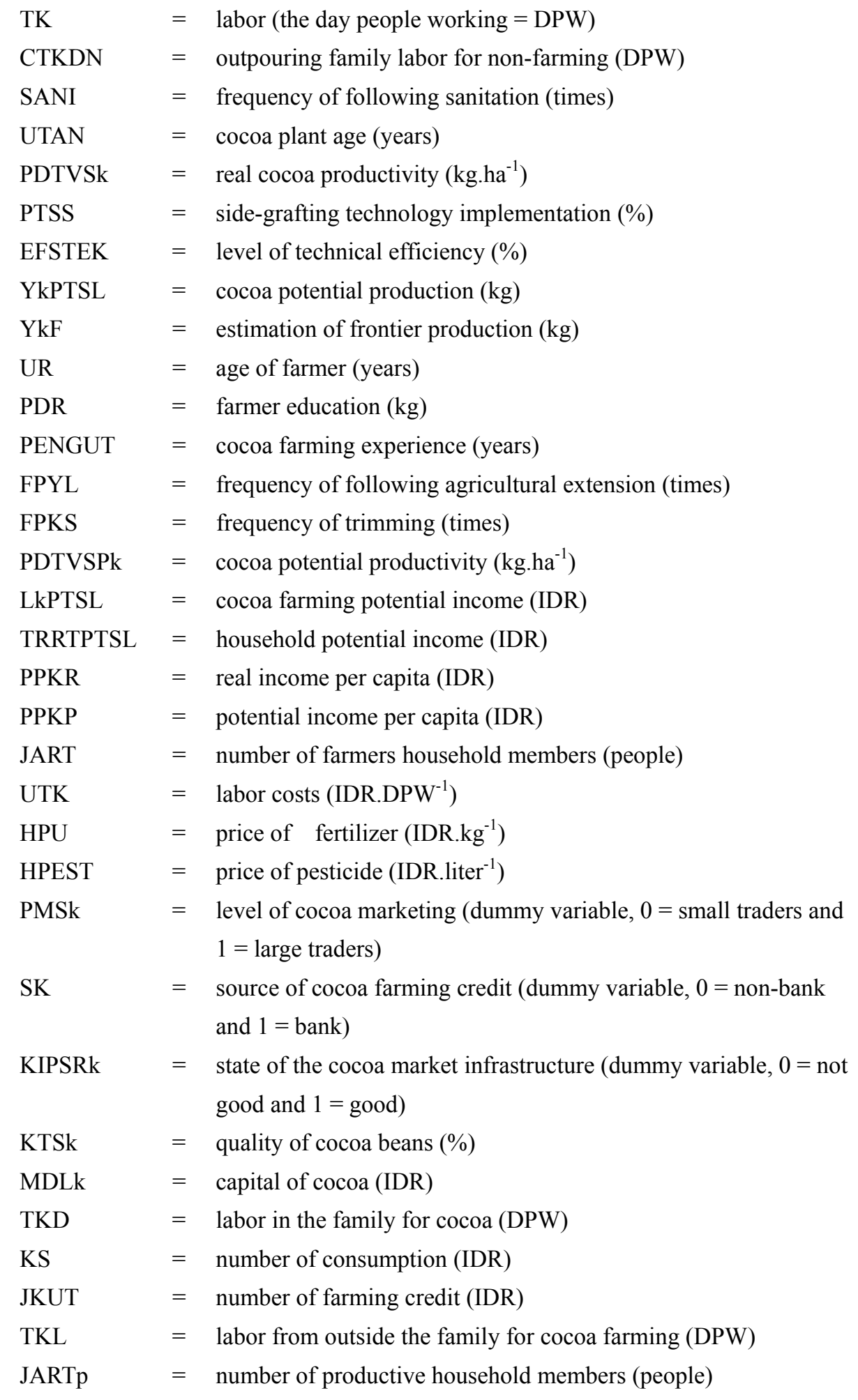

Because all overidentified equation, so the method of Two Stage Least Squares (TSLS) can be used (Koutsoyiannis, 1978). Data processing was performed with SAS 9.1 program.

\section{Results}

\subsection{Model Validation}

Model Validation aimed to determine whether the estimation value corresponding to the actual value of each endogenous variable (Pindyck and Rubinfield, 1991). Model validation was done before simulation analysis was done. The results of statistical tests to predict the economic model of cocoa farmers household are shown on 
Table 1.

Table 1 shows that the average relative prediction closer to the actual average so the models had good results. $\mathrm{U}^{\mathrm{M}}$ values closed to zero which meant that the model did not have a systematic bias. $\mathrm{U}^{\mathrm{S}}$ value closed to zero meant that the prediction results of the simulation analysis could be followed by either actual data fluctuations. $\mathrm{U}^{\mathrm{C}}$ value closed to one that meant the prediction error did not mean and did not follow a specific pattern and its distribution followed the actual data. Based on the analysis of model validation could be concluded that the model was good enough to use as a model estimation, therefore structural model had been formulated valid enough to be used as a simulation tool.

Table 1. Results of economy model validation of cocoa farming household

\begin{tabular}{crrrrl}
\hline Variables & Actuals Mean & Predictions Mean & $\left(\mathrm{U}^{\mathrm{M}}\right)$ & $\left(\mathrm{U}^{\mathrm{S}}\right)$ & $\left(\mathrm{U}^{\mathrm{C}}\right)$ \\
\hline TRRT & $29,266,493.000$ & $29,828,701.000$ & 0.01 & 0.00 & 0.99 \\
Lk & $22,483,585.000$ & $23,074,343.000$ & 0.01 & 0.01 & 0.98 \\
NonUST & $6,782,908.000$ & $6,754,358.000$ & 0.00 & 0.10 & 0.90 \\
LAPk & 1.633 & 1.632 & 0.00 & 0.01 & 0.99 \\
PDTVSk & 996.100 & 996.000 & 0.00 & 0.07 & 0.93 \\
Yk & $1,629.600$ & $1,645.400$ & 0.00 & 0.00 & 1.00 \\
YkPTSL & $1,628.800$ & $1,629.400$ & 0.00 & 0.01 & 0.99 \\
JKUT & $3,436,224.000$ & $3,435,575.000$ & 0.00 & 0.07 & 0.93 \\
EFSTEK & 0.808 & 0.808 & 0.00 & 0.07 & 0.93 \\
PDTVSPk & 996.600 & 987.800 & 0.00 & 0.16 & 0.84 \\
LkPTSL & $22,459,461.000$ & $22,649,080.000$ & 0.00 & 0.01 & 0.99 \\
TRRTPTSL & $29,242,369.000$ & $29,403,438.000$ & 0.00 & 0.03 & 0.97 \\
PPKR & $729,595.000$ & $742,282.000$ & 0.00 & 0.00 & 0.99 \\
PPKP & $729,098.000$ & $730,697.000$ & 0.00 & 0.04 & 0.96 \\
TVC & $12,397,706.000$ & $12,238,808.000$ & 0.00 & 0.04 & 0.95 \\
Pk & $20,806.200$ & $20,826.500$ & 0.00 & 0.05 & 0.95 \\
PMSk & 1.500 & 1.504 & 0.00 & 0.15 & 0.85 \\
KTSk & 0.896 & 0.896 & 0.00 & 0.13 & 0.87 \\
MDLk & $12,397,706.000$ & $12,364,891.000$ & 0.00 & 0.04 & 0.96 \\
PTSS & 0.397 & 0.397 & 0.00 & 0.08 & 0.92 \\
TK & 209.700 & 209.900 & 0.00 & 0.03 & 0.97 \\
TKL & 120.500 & 120.400 & 0.00 & 0.07 & 0.93 \\
TKD & 89.255 & 89.577 & 0.00 & 0.18 & 0.82 \\
CTKDN & 164.000 & 162.700 & 0.00 & 0.15 & 0.85 \\
KS & $27,445,053.000$ & $27,894,635.000$ & 0.01 & 0.00 & 0.99 \\
YkF & $2,003.000$ & $2,004.700$ & 0.00 & 0.02 & 0.98 \\
PU & 895.900 & 895.300 & 0.00 & 0.02 & 0.98 \\
\hline SOur & & & &
\end{tabular}

Source: Analysis results of SAS 9.1 program.

\subsection{Simulation Analysis}

The objectives of model simulation are for performing the testing and evaluating of models, evaluating policies in the past, making forecasting for the future (Pyndick and Rubinfield, 1991). Simulation is needed to study the impact of changes in exogenous variables on the endogenous variables in the model.

The simulation in this research was made between the period (ex-post simulation) or historical simulation. This simulation aimed to analyze the linkage of production decisions, labor allocation, and consumption in increasing household income of cocoa farmers. Some combination simulation that would be done are as follows:

(a). The increasing linkage of fertilizer usage and agricultural extension by $25 \%$ to the household economy;

(b). The increasing linkage of fertilizer usage and sanitation by $25 \%$ to the household economy;

(c). The increasing linkage of fertilizer usage, agricultural extension and sanitation by $25 \%$ to the household economy.

Combination simulation analysis are shown on Table 2. Table 2 shows that the combination simulation had 
positive impact in household income of cocoa farmers. The highest of change in household income of cocoa farmers were $18.1 \%$ contained in the simulation of fertilizer usage increasing, agricultural extension and sanitation by $25 \%$. It meant that farmers could increase household income by increasing the usage of fertilizer, following the agricultural extension and sanitation.

Table 2. Combination simulation of some variables in change of household economic of cocoa farmers

\begin{tabular}{|c|c|c|c|c|}
\hline \multirow[b]{2}{*}{ Variables } & \multirow[b]{2}{*}{ Basic Simulations } & \multicolumn{3}{|c|}{ Change $(\%)$} \\
\hline & & $\begin{array}{c}\text { Simulations } \\
\text { (a) }\end{array}$ & $\begin{array}{c}\text { Simulations } \\
\text { (b) }\end{array}$ & $\begin{array}{c}\text { Simulations } \\
\text { (c) }\end{array}$ \\
\hline TRRT & $29,828,701.000$ & 14.04 & 13.96 & 18.09 \\
\hline Lk & $23,074,343.000$ & 20.21 & 20.18 & 26.15 \\
\hline NonUST & $6,754,358.000$ & -7.04 & -7.29 & -9.47 \\
\hline LAPk & 1.632 & 2.51 & 4.94 & 5.63 \\
\hline PDTVSk & 996.000 & 9.65 & 7.57 & 10.26 \\
\hline $\mathrm{Yk}$ & $1,645.400$ & 12.45 & 13.10 & 16.65 \\
\hline YkPTSL & $1,629.400$ & 5.55 & 5.15 & 8.87 \\
\hline JKUT & $3,435,575.000$ & 12.61 & 14.26 & 17.73 \\
\hline EFSTEK & 0.808 & 2.81 & 0.71 & 3.53 \\
\hline PDTVSPk & 987.800 & 3.00 & 0.13 & 3.02 \\
\hline LkPTSL & $22,649,080.000$ & 9.55 & 7.80 & 14.02 \\
\hline TRRTPTSL & $29,403,438.000$ & 5.74 & 4.33 & 8.62 \\
\hline PPKR & $742,282.000$ & 13.81 & 14.03 & 17.86 \\
\hline PPKP & $730,697.000$ & 5.41 & 4.33 & 8.28 \\
\hline TVC & $12,238,808.000$ & 3.82 & 6.23 & 7.34 \\
\hline $\mathrm{Pk}$ & $20,826.500$ & 1.66 & 1.81 & 2.28 \\
\hline PMSk & 1.504 & 3.46 & 3.64 & 4.63 \\
\hline KTSk & 0.896 & 0.75 & 0.89 & 1.09 \\
\hline MDLk & $12,364,891.000$ & 10.26 & 11.86 & 14.65 \\
\hline PTSS & 0.397 & 11.68 & - & 11.68 \\
\hline TK & 209.900 & 3.86 & 6.67 & 7.77 \\
\hline TKL & 120.400 & 2.66 & 5.81 & 6.48 \\
\hline TKD & 89.577 & 5.41 & 7.79 & 9.34 \\
\hline CTKDN & 162.700 & -6.21 & -6.64 & -8.48 \\
\hline KS & $27,894,635.000$ & 12.00 & 11.94 & 15.47 \\
\hline $\mathrm{YkF}$ & $2,004.700$ & 2.62 & 4.26 & 4.98 \\
\hline PU & 895.300 & 4.38 & 6.61 & 7.82 \\
\hline
\end{tabular}

Source: Analysis results of SAS 9.1 program.

\section{Discussion}

Simulations (a), (b), and (c) show the increasing in cocoa farming income. The highest increasing occurred in the simulation of fertilizer usage increasing, agricultural extension and sanitation by $25 \%$. This increasing caused labors absorption increased $7.77 \%$, that consisted of labor from outside the family were $6.48 \%$ and labor from inside the family were $9.34 \%$.

The usage of fertilizer affects on production increasing and productivity of cocoa. The research of Li et al. (2008) shows that the fertilizer affects on agricultural production in China. The increasing of cocoa production and productivity will increase cocoa farming income.

Extension affects on increasing the technical efficiency of farmers so that can increase the productivity of cocoa. The research of Rahman and Hasan (2008), Jahan and Pemsl (2011), and Rahman and Rahman (2008) conclude that the increasing of extension service will increase the technical efficiency of farmers so that agricultural production will increase.

Sanitation would have a positive impact on the household income of cocoa farmers. It was caused of sanitation affected on increasing the technical efficiency of farmers so that could increase the productivity of cocoa. Sanitation of rotten fruit is proven to reduce the source of inoculum, so it helps in reducing the intensity of the 
attack and the rate of disease infection (Bagian Proyek Penelitian Kopi dan Kakao, 2001). The spread of cocoa pests and diseases are caused by poor sanitation management. Insects played an important role in the disease cycle of rotten fruit (Phytophthora). Sanitation will spur hygiene of tree and improve health of plant (Konam and Namaliu, 2009).

The increasing of cocoa farming income by $26.15 \%$ in the simulation of fertilizer usage increasing, agricultural extention and sanitation by $25 \%$ had negative impact on the outpouring of family labor off-farm activities. It showed the value of on-farm marginal was higher than off-farm. According to Gronau (1973) and Becker (1965), that in perfectly competitive market, individual will participate in off-farm during their marginal value is smaller than wage rate from off-farm. Outpouring of family labor in off-farm activities decreased $8.48 \%$ that meant family labor tended to use the time to rest than looked for income outside of cocoa farming.

The increasing of farmers household income affects on the household expenses. The higher of farmers household income, the higher the household expenses to fulfill consumption needs. The increasing of household income were $18.09 \%$ in the simulation of fertilizer usage increasing, agricultural extension and sanitation by $25 \%$ caused the increasing of expenses for consumption by $15.47 \%$. The research of Skoufias (1994), Jacoby (1993), and Abdulai and Regmi (2000) show that between production and consumption decisions are inseparable. Food and non-food consumption in this research showed the increasing in quantity and quality, as well as the quality of education and health were obtained also increased.

\section{Conclusions}

Combination simulation by increasing the usage of fertilizer, following agricultural extension and sanitation by $25 \%$ as production decisions had positive impacts in increasing household income of cocoa farmers $(18.09 \%)$, labors absorption (7.77\%) and expenses for consumption (15.47\%). To increase the household income, farmers should increase the usage of fertilizer, following agricultural extension, sanitation, and increase the next generation of resources through formal education.

\section{Acknowledgments}

The author would like to thank the Director General of Higher Education Indonesia, which had helped fund this research. The author also thanks the reviewers who had took time to perfect this manuscript.

\section{References}

Abdulai, A., \& Regmi, P. P. (2000). Estimating labour supply of farm household under nonseparability:

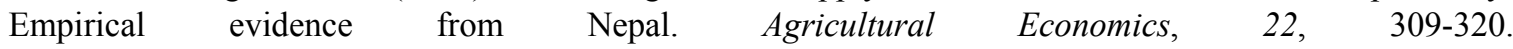
http://dx.doi.org/10.1111/j.1574-0862.2000.tb00077.x

Bagian Proyek Penelitian Kopi dan Kakao. (2001). Laporan kegiatan penelitian Tahun Anggaran 2001. Jember: Pusat Penelitian Kopi dan Kakao.

Becker, G. (1965). A theory of the allocation of time. The Economic Journal, 75, 493-517. http://dx.doi.org/10.2307/2228949

Departemen Pertanian Direktorat Jenderal Perkebunan. (2009). Buku Panduan Teknis Budidaya Tanaman Kakao (Theobroma cacao L.). Gerakan Peningkatan Produksi dan Mutu Kakao Nasional.

Elly, F. H., Sinaga, B. M., Kuntjoro, S. U., \& Kusnadi, N. (2009). Impact on transaction cost of household economic cattle farmers in Minahasa. Forum Pascasarjana, 32(3), 195-213.

Gronau, R. (1973). The intra family allocation of time: the value of the housewife's time. American Economic Review, 63, 634-651.

Jacoby, H. (1993). Shadow wages and peasant family labour supply: an econometric application to the Peruvian Sierra. Review of Economic Studies, 60, 903-922. http://dx.doi.org/10.2307/2298105

Jahan, K. M. E., \& Pemsl, D. E. (2011). The impact of integrated aquaculture-agriculture on small-scale farm sustainability and farmers' livelihoods: Experience from Bangladesh. Agricultural Systems, 104, 392-402. http://dx.doi.org/10.1016/j.agsy.2011.01.003

Konam, J., \& Namaliu, Y. (2009). Pengelolaan Hama dan Penyakit Terpadu untuk Produksi Kakao Berkelanjutan, Panduan pelatihan untuk petani dan penyuluh. Divisi Penyakit Tumbuhan, Lembaga Kelapa Kakao, Papua Nugini. Cocoa Coconut Institute Papua New Guinea Universitas Sydney, Australia.

Koutsoyiannis, A. (1978). Theory of Econometrics: An Introductory Exposition of Econometric Methods. Second Edition. The MacMillan Press Ltd., London. 
Li, X., Luo, Y., Gao, Q., Dong, S., \& Yang, X. (2008). Farm Production Growth in the Upper and Middle Parts of the Yellow River Basin, China, During 1980-1 999. Agricultural Sciences in China, 7(3), 344-355. http://dx.doi.org/10.1016/S1671-2927(08)60075-9

Lokolo, E. M. (2001). Market Dependency and Household Food Consumption in East Java, Indonesia. Jurnal Agro Ekonomi, 19(2), 17-35.

Neilson, J. (2008). Program Gerakan Nasional Percepatan Revitalisasi Kakao Nasional (GERNAS). Masukan strategis dari Forum Kemitraan Kakao Berkelanjutan (Cocoa Sustainability Partnership), ACIAR. Retrieved November 11, 2012, from http://www.google.co.id/\#bav=on.2,or.r_qf.\&fp=442bdad5c6096e1d\&q= Program+Gerakan+Nasional+Percepatan+Revitalisasi+Kakao+Nasional+\%28GERNAS\%29.

Parel, C. P., Caldito, G. C., Ferrer, P. L., De Guzman, G. G., Sinsioco, C. S., \& Tan, R. H. (1973). Sampling Design and Procedures. The Agricultural Development Council. Quezon City.

Pindyck, R. S., \& Rubinfeild, D. L. (1991). Econometric Models and Economic Forcasts. Third Edition. McGarw-Hill Inc., New York.

Rahman, S., \& Hasan, M. K. (2008). Impact of environmental production conditions on productivity and efficiency: A case study of wheat farmers in Bangladesh. Journal of Environmental Management, 88, 1495-1504. http://dx.doi.org/10.1016/S1671-2927(08)60075-9

Rahman, S., \& Rahman, M. (2008). Impact of land fragmentation and resource ownership on productivity and efficiency: The case of rice producers in Bangladesh. Land Use Policy, 26, 95-103. http://dx.doi.org/10.1016/j.landusepol.2008.01.003

Rochaeni, S., \& Lokolo, E. M. (2005). The Factors that Affected Household Economic Decision of Farmer in Setugede Bogor Village. Jurnal Agro Ekonomi, 23(2), 133-158.

Siswati, L., \& Ariyanto, A. (2012). Household Economic Farmers : Integrated Farming in the Province of Riau. Jur. Embrio, 5(1), 8-17.

Skoufias, E. (1994). Using shadow wages to estimate labour supply of agricultural household. American Journal of agricultural Economics, 75, 20-32. http://dx.doi.org/10.2307/1242950

\section{Copyrights}

Copyright for this article is retained by the author(s), with first publication rights granted to the journal. This is an open-access article distributed under the terms and conditions of the Creative Commons Attribution license (http://creativecommons.org/licenses/by/3.0/). 